\title{
Pengaruh kompensasi terhadap kepuasan kerja karyawan pada PT. Sumber Hijau Permai (SHP) Jambi
}

\author{
Izmi Anisa Oktaviani*; Indra Jaya; Rohman Willian
}

\author{
Program Studi Manajemen Fakultas Ekonomi dan Bisnis Universitas Jambi \\ *E-mail korespodensi: izmianisa@gmail.com
}

\begin{abstract}
This study aims to obtain an overview of employees' compensation and job satisfaction at the PT. Sumber Hijau Permai (SHP) Jambi. Furthermore, to explain the effect of payment on employee job satisfaction. The study population was employees at the PT. Sumber Hijau Permai (SHP) Jambi totaling 87 people. The sampling method uses the census method, meaning that all present population was sampled. Based on the research objectives, the type of research is explanatory research (explanatory research) done to explain the causal relationship between research variables through hypothesis testing. The hypothesis is tested using a simple linear regression equation using SPSS 17.0 for Windows. Descriptive results of this study indicate that the compensation received by employees is categorized as entirely reasonable and employee satisfaction in the work. Employees feel pretty satisfied in his job. Furthermore, the magnitude role or contribution of variable compensation can explain the variable job satisfaction of employees is 56,2\%. At the same time, the remaining 43,8\% is influenced by other factors which are not disclosed in this study.
\end{abstract}

Keywords : compensation, job satisfaction

\begin{abstract}
Abstrak
Penelitian ini bertujuan untuk memperoleh gambaran tentang kompensasi dan kepuasan kerja karyawan pada PT. Sumber Hijau Permai (SHP) Jambi. Selanjutnya untuk menjelaskan pengaruh kompensasi terhadap kepuasan kerja karyawan. Populasi penelitian ini adalah karyawan pada PT. Sumber Hijau Permai (SHP) Jambi berjumlah 87 orang. Metode pengambilan sampel menggunakan metode sensus, artinya semua populasi yang ada dijadikan sampel. Berdasarkan tujuan penelitian, maka jenis penelitiannya adalah penelitian eksplanatori (explanatory research) yang dilakukan untuk menjelaskan hubungan sebab akibat antara variabel penelitian melalui pengujian hipotesis. Sedangkan untuk pengujian hipotesisnya sendiri menggunakan persamaan regresi linier sederhana dengan menggunakan SPSS 17.0 for Windows. Hasil deskriptif penelitian ini menunjukkan bahwa kompensasi yang diterima karyawan dikategorikan cukup baik, begitu juga dengan kepuasan karyawan dalam bekerja, karyawan merasa cukup puas dalam pekerjaannya. Selanjutnya besarnya peran atau kontribusi variabel kompensasi mampu menjelaskan variabel kepuasan kerja karyawan sebesar 56,2\%. Sedangkan sisanya sebesar $43,8 \%$ dipengaruhi oleh faktor lain yang tidak diungkapkan dalam penelitian ini.
\end{abstract}

Kata kunci : kompensasi, kepuasan kerja

PENDAHULUAN

Sumber daya manusia adalah bagian dari perusahaan yang mampu bergerak secara dinamis dan menentukan strategi perusahaan dalam mengarungi persaingan bisnis. Salah satu sasaran penting dalam manajemen sumber daya manusia adalah terciptanya 
kepuasan kerja karyawan. Kepuasan kerja karyawan menjadi masalah yang cukup menarik dan penting, karena terbukti besar manfaatnya baik bagi kepentingan karyawan maupun perusahaan.

Kepuasan kerja merupakan sikap umum terhadap pekerjaan seseorang, yang menunjukkan perbedaan antara jumlah pengharagaan yang diterima pekerja dan jumlah yang mereka yakini seharusnya mereka terima (Robbins, 2003). Kepuasan kerja merupakan salah satu faktor penentu/keberhasilan suatu pekerjaan . Hal ini disebabkan karena kepuasan kerja dapat mempengaruhi perilaku kerja seperti malas, rajin, produktif dan lain-lain, atau mempunyai hubungan dengan beberapa jenis perilaku yang sangat penting dalam berperilaku.

Menurut Martoyo (2000) kepuasan kerja merupakan salah satu aspek psikologis yang mencerminkan perasaaan seseorang terhadap pekerjaannya, ia akan merasa puas dengan adanya kesesuaian antara kemampuan, ketrampilan dan harapannya dengan pekerjaan yang ia hadapi. Selain itu kepuasan kerja berperan penting dalam kemampuan perusahaan untuk menarik dan memelihara karyawan yang berkualitas dan mempunyai arti penting baik bagi karyawan maupun perusahaan, terutama karena menciptakan keadaan positif di dalam lingkungan kerja atau perusahaan. Kepuasan kerja menjadi hal penting yang harus selalu diperhatikan perusahaan, karena dengan adanya kepuasan ini karyawan akan memberikan prestasi kerja yang tinggi, dan sebaliknya apabila kepuasan yang dirasakan karyawan rendah hal ini akan memberikan pengaruh negatif yaitu terciptanya ketidakpuasan kerja. Banyak faktor yang mempengaruhi kepuasan kerja karyawan, faktor-faktor itu sendiri dalam peranannya memberikan kepuasan kepada karyawan. Menurut Robbins (2003) faktor-faktor yang mempengaruhi kepuasan kerja yaitu pekerjaan yang secara mental menantang, imbalan yang wajar, kondisi lingkungan yang mendukung, dan rekan kerja yang supportif. Diantara beberapa faktor tersebut salah satu faktor penting yang mempengaruhi kepuasan kerja dalam suatu perusahaan yaitu gaji atau kompensasi.

Kompensasi merupakan imbalan yang diterima oleh karyawan sebagai balas jasa atas pekerjaan yang dilakukan dan diselesaikan oleh karyawan yang diberikan perusahaan. Kompensasi yang diberikan dapat berupa kompensasi langsung maupun kompensasi tidak langsung. Rivai dan Sagala (2011) mendefinisikan bahwa kompensasi merupakan semua bentuk imbalan jasa atau balas jasa yang diberikan perusahaan sebagai penghargaan pada karyawan yang telah memberikan tenaga dan pikiran sebagai kontribusi dalam mewujudkan tujuan perusahaan sebagai imbalan balik dari pekerjaan mereka.

Kompensasi yang diterima merupakan sebuah imbalan atas sesuatu yang telah dikerjakan para karyawan terhadap organisasinya, kompensasi berupa upah tentu saja dicari seorang karyawan agar ia dapat memenuhi kebutuhannya. Salah satu cara yang tepat bagi perusahaan untuk memenuhi kebutuhan sumber daya manusia tersebut yaitu dengan cara memberikan kompensasi yang layak dan adil sebagai penghargaan yang diberikan perusahaan kepada karyawannya (Sutrisno, 2013). Kompensasi seringkali menjadi pemicu ketidakpuasan karyawan.Organisasi sebaiknya dapat membuat suatu sistem kompensasi yang dapat mendorong adanya kepuasan kerja bagi karyawannya, yang pada gilirannya akan membentuk sikap positif dan produktif.

PT. Sumber Hijau Permai (SHP) Jambi merupakan perusahaan yang bergerak dalam bidang usaha pemanfaatan hasil hutan dan kayu tanaman yang telah melakukan upaya untuk meningkatkan kepuasan kerja karyawannya dalam usaha untuk memberikan kualitas. Untuk mencapai keadaan tersebut maka perusahaan menganggap pemberian kompensasi kepada karyawan sangatlah penting. Hal ini terlihat dari karyawan yang merasa puas akan termotivasi untuk melakukan pekerjaannya dengan baik.

Berdasarkan pasal 89 UU Ketenagakerjaan mengatur bahwa upah minimum ditetapkan pemerintah berdasarkan kebutuhan hidup layak dan dengan memperhatikan 
produktivitas dan pertumbuhan ekonomi. Upah minimum dapat terdiri atas upah berdasarkan wilayah provinsi (UMP), dan upah berdasarkan kabupaten/kota. Pengusaha dilarang membayar upah lebih rendah dari upah minimum sebagaimana yang telah diatur dalam pasal 89 UU Ketenagakerjaan. Seiring dengan penetapan Upah Minimum Provinsi Jambi per 1 Januari 2017 oleh pemerintah dengan jumlah Rp. 2.063.000,-- Namun berdasarkan hasil wawancara kepada beberapa responden belumlah begitu puas dengan pekerjaan yang mereka laksanakan ini, hal ini berkaitan dengan kompensasi yang mereka terima belum sesuai dengan harapan. Karena sudah lebih kurang dari satu tahun belakang ini tidak pernah ada kenaikan gaji bahkan masih ada beberapa karyawan yang menerima gaji dibawah upah minimum provinsi (UMP). selain itu Menurut Humaeroh (2015) pemberian kompensasi yang setimpal akan membuat sumber daya manusia merasa dihargai dengan baik. Pada akhirnya sumber daya manusia akan merasakan kepuasan dalam bekerja pada sebuah perusahaan tersebut.

Berdasarkan berbagai uraian dan permasalahan diatas, maka penelitian ini bertujuan untuk mengetahui pengaruh kompensasi terhadap kepuasan kerja karyawan pada PT. Sumber Hijau Permai (SHP) Jambi. Variabel yang digunakan dalam penelitian ini adalah kompensasi dan kepuasan kerja karyawan. Diharapkan dengan dilakukan penelitian ini akan diperoleh konsep mengenai pengaruh kompensasi terhadap kepuasan kerja karyawan pada PT. Sumber Hijau Permai (SHP) Jambi. Berdasarkan pada uraian tersebut penulis tertarik untuk melakukan penelitian dengan judul "Pengaruh kompensasi terhadap kepuasan kerja karyawan pada PT. Sumber Hijau Permai (SHP) Jambi”.

\section{TINJAUAN PUSTAKA}

\section{Kepuasan kerja}

Menurut Sutrisno (2009) Kepuasan kerja adalah suatu sikap karyawan terhadap pekerjaan yang berhubungan dengan situasi kerja, kerja sama antar karyawan, imbalan yang diterima dalam kerja, dan hal-hal yang menyangkut faktor fisik dan psikologis. sikap terhadap pekerjaan ini merupakan hasil dari sejumlah sikap khusus individu dan hubungan sosial individu diluar pekerjaan sehingga menimbulkan sikap umum individu terhadap pekerjaan yang dihadapinya.

Menurut Robbins (2003) kepuasan kerja merupakan sikap umum terhadap pekerjaan seseorang, yang menunjukkan perbedaan antara jumlah penghargaan yang diterima pekerja dan jumlah yang mereka yakini seharusnya mereka terima. Kepuasan kerja yang dirasakan akan ditunjukan dengan sikap pegawai dalam bekerja.

Dari beberapa pendapat para ahli diatas dapat diambil kesimpulan bahwa kepuasan kerja adalah perasaan atau sikap seseorang terhadap pekerjaan yang dilakukannya, yang dapat dipengaruhi oleh berbagai macam faktor.

Banyak faktor yang mempengaruhi kepuasan kerja. Menurut Hasibuan (2007) kepuasan kerja karyawan dipengaruhi oleh faktor-faktor : 1)Balas jasa yang adil dan layak, 2)Penempatan yang tepat sesuai dengan keahlian, 3)Berat ringannya pekerjaan, 4)Suasana dan lingkungan pekerjaan, 5)Peralatan yang menunjang pelaksanaan pekerjaan, 5)Sikap pimpinan dalam kepemimpinannya., 6)Sifat pekerjaan monoton atau tidak.

Menurut Luthans dalam Sopiah (2008) adalah: pekerjaan itu sendiri, sejauh mana Karyawan memandang

pekerjaannya sebagai pekerjaan yang menarik, memberikan kesempatan untuk belaja, dan peluang untuk menerima tanggung jawab. Gaji, merupakan jumlah balas jasa finansial yang diterima karyawan dan tingkat dimana hal ini dipandang sebagai suatu hal yang adil dalam organisasi. Promosi, kesempatan untuk kenaikkan jabatan dalam jenjang karir. Supervisi, merupakan kemampuan penyelia untuk memberikan bantuan secara 
teknis maupun memberikan dukungan. Kelompok kerja/ rekan kerja, merupakan suatu tingkatan dimana rekan kerja memberikan dukungan.

Kondisi kerja, apabila kondisi kerja karyawan baik ( bersih menarik dan lingkungan kerja yang menyenangkan) akan membuat mereka mudah menyelesaikan pekerjaannya. Dari beberapa teori yang telah dikemukakan oleh para ahli, untuk mengukur variabel kepuasan kerja dalam penelitian ini penulis menggunakan teori yang dikemukakan oleh Robbins (2003) dengan indikator sebagai berikut:

\section{Pekerjaan}

Tingkat dimana sebuah pekerjaan menyediakan tugas yang menyenangkan, kesempatan

belajar, dan kesempatan untuk mendapatka tanggung jawab. Hal ini menjadi sumber mayoritas kepuasan kerja. Isi pekerjaan yang dilakukan seseorang apakah memiliki elemen yang memuaskan.

\section{Upah}

Jumlah bayaran yang diterima seseorang sebagai akibat dari pelaksanaan kerja apakah sesuai dengan kebutuhan yang dirasakan adil. Gaji diakui merupakan faktor yang signifikan terhadap kepuasan kerja.

\section{Promosi}

Karyawan memiliki kesempatan untuk mengembangkan diri dan memperluas pengalaman kerja, dengan terbukanya kesempatan untuk kenaikan jabatan.

\section{Pengawasan}

Kemampuan supervisor untuk menyediakan bantuan teknis dan perilaku dukungan. Seseorang yang senantiasa memberikan perintah atau petunjuk dalam pelaksanaan kerja. Hubungan fungsional dan hubungan keseluruhan yang positif memberikan tingkat kepuasan kerja yang paling besar dengan atasan.

\section{Rekan kerja}

Kebutuhan dasar manusia untuk melakukan hubungan sosial akan terpenuhi dengan adanya rekan kerja yang mendukung karyawan. Jika terjadi konflik dengan rekan kerja akan berpengaruh pada tingkat kepuasan kerja karyawan terhadap pekerjaan. Seseorang dapat merasakan rekan kerjanya sangat menyenangkan atau tidak menyenangkan.

\section{Kompensasi}

Menurut Hasibuan (2012), kompensasi adalah semua pendapatan yang berbentuk uang, barang langsung atau tidak langsung yang diterima karyawan sebagai imbalan atas jasa yang diberikan kepada perusahaan. Menurut Sedarmayanti (2009), kompensasi adalah segala sesuatu yang diterima oleh pegawai sebagai balas jasa untuk kerja mereka. Dalam suatu organisasi masalah kompensasi merupakan masalah yang sangat kompleks, namun penting bagi pegawai maupun organisasi itu sendiri. Pemberian kompensasi kepada pegawai harus mempunyai dasar yang rasional, namun faktor emosional dan prikemanusiaan tidak boleh diabaikan.

Menurut Rivai dan Sagala (2011) mengemukakan bahwa kompensasi merupakan sesuatu yang diterima karyawan sebagai pengganti kontribusi jasa mereka pada perusahan. Pemberian kompensasi merupakan salah satu pelaksanaan fungsi manajemen sumberdaya manusia yang berhubungan dengan semua jenis penghargaan individual sebagai pertukaran dalam melakukan tugas keorganisasian.

Jadi dapat disimpulkan bahwa kompensasi merupakan semua bentuk imbalan jasa atau balas jasa yang diberikan perusahaan sebagai penghargaan pada karyawan yang telah memberikan tenaga dan pikiran sebagai kontribusi dalam mewujudkan tujuan perusahaan sebagai imbalan balik dari pekerjaan mereka. 
Dari beberapa teori yang telah dikemukakan oleh para ahli, untuk mengukur variabel kompensasi dalam penelitian ini penulis menggunakan teori yang dikemukakan oleh Rivai dan Sagala (2011) dengan indikator sebagai berikut:

\section{Kompensasi finansial}

Kompensasi langsung :1).Gaji, 2)Insentif, 3). Uang lembur kompensasi tidak langsung:1).Tunjangan, 2).Fasilitas kerja kompensasi non finansial:1)Pujian, 2).Penghargaan, 3).Pengakuan, 4).Cuti kerja

\section{Kerangka berpikir}

Hipotesis dalam penelitian ini adalah diduga kompensasi berpengaruh positif dan signifikan terhadap kepuasan kerja karyawan PT. Sumber Hijau Permai (SHP) Jambi.

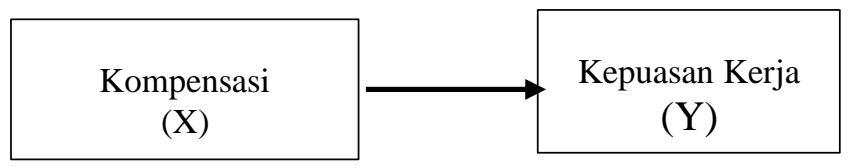

Gambar 1. Kerangka berpikir

\section{METODE}

\section{Populasi dan sampel}

Adapun populasi dalam penelitian ini adalah karyawan PT. Sumber Hijau Permai (SHP) Jambi yang berjumlah 87 orang. Dikarenakan jumlah populasi dalam penelitian ini kurang dari 100 orang maka dalam penelitian ini metode pengambilan sampel menggunakan metode sensus dimana semua karyawan dijadikan sebagai sampel penelitian, sehingga jumlah sampel dalam penelitian ini adalah sebanyak 87 orang karyawan.

\section{Metode pengumpulan data}

Untuk mengumpulkan data yang akan diperlukan untuk menganalisis data dalam penelitian ini, yaitu pengumpulan data primer. Teknik pengumpulan data yang digunakan dalam penelitian ini adalah teknik pengumpulan data dengan menggunakan kuesioner. Kuesioner adalah teknik pengumpulan data yang dilakukan dengan cara memeberi seperangkat pertanyaan-pertanyaan tertulis kepada responden untuk dijawab. Kuesioner merupakan teknik pengumpulan data yang efisien bila peneliti tahu dengan pasti variabel yang akan diukur dan tahu apa yang bisa diharapkan dari responden.

Skala yang digunakan dalam penelitian ini adalah skala Likert. Menurut Ghozali (2011), skala Likert adalah skala yang berisi 5 (lima) tingkat preferensi jawaban dengan pilihan sebagai berikut:Sangat tidak setuju, Tidak Setuju, Cukup Setuju, Setuju, Sangat Setuju

\section{Visi dan misi PT. Sumber Hijau Permai (SHP) Jambi}

\section{Visi}

Terwujudnya pengelolaan sumber daya hutan sebagai ekosistem secara efisien dan profesional guna menjamin kelestarian fungsi produksi, ekologi dan sosial.

\section{Misi}

Membangun dan mengelola hutan tanaman dengan tujuan produksi kayu secara optimal dengan menerapkan teknologi tepat guna dan dengan dukungan manajerial dan sumber daya manusia yang handal dan profesional. Meningkatkan mutu lingkungan hidup melalui pengelolaan sumber daya alam hayati dan ekosistemnya. 
Melakukan perlindungan dan konservasi keanekaragaman hayati beserta ekosistemnya. Mengelola sumberdaya hutan sebagai ekosistem secara partisipatif sesuai dengan karakteristik wilayah. Meningkatkan manfaat ekonomi dan peran serta masyarakat setempat secara langsung maupun tidak langsung.

\section{HASIL DAN PEMBAHASAN}

\section{Uji validitas}

Uji validitas digunakan untuk mengukur sah atau tidaknya kuesioner. Cara yang dilakukan yaitu dengan membandingkan nilai $r$ hitung dari masing-masing item indikator dengan $r$ tabel dengan derajat kebebasan (degree of freedom) atau $\mathrm{df}=\mathrm{n}-2$ atau $(87-2=85)$ diperoleh nilai $r$ tabel sebesar 0,1775. Syarat minimum untuk dianggap memenuhi syarat adalah jika $r$ hitung > $r$ tabel maka butir pernyataan dinyatakan valid (Sugiyono, 2012). Berikut adalah hasil pengujian untuk masing-masing indikator dan variabel:

Tabel 1. Hasil uji validitas variabel kompensasi

\begin{tabular}{|c|c|c|c|c|}
\hline Variabel & $\mathbf{X}$ & r hitung & $r$ tabel & Keterangan \\
\hline \multirow{9}{*}{ Kompensasi (X) } & X.1 & 0.653 & 0.1775 & Valid \\
\hline & X ? & $\cap 781$ & ก 1775 & Valid \\
\hline & X 3 & ก 418 & 0 1775 & Valid \\
\hline & X.4 & 0.605 & 0.1775 & Valid \\
\hline & X.5 & 0.688 & 0.1775 & Valid \\
\hline & X. 6 & 0.618 & 0.1775 & Valid \\
\hline & $\times 7$ & ก 574 & ก 1775 & Valid \\
\hline & $\hat{X} 8$ & 0650 & 01775 & Valid \\
\hline & X.9 & 0,576 & 0,1775 & Valid \\
\hline
\end{tabular}

Sumber: Data diolah, 2018

Berdasarkan Tabel 1 terlihat bahwa nilai $\mathrm{r}$ hitung setiap item pada variabel kompensasi lebih besar dari nilai $r$ tabel atau $r$ hitung $>r$ tabel dimana batas angka kritis adalah 0,05 dan $\mathrm{n}=87$ maka diperoleh $\mathrm{r}$ tabel sebesar 0,1775. Maka dapat disimpulkan bahwa variabel kompensasi bersifat valid.

Tabel 2. Hasil uji validitas variabel kepuasan kerja

\begin{tabular}{ccccc}
\hline Variabel & Y & r hitung & r tabel & Keterangan \\
\cline { 2 - 5 } & Y.1 & 0,646 & 0,1775 & Valid \\
Kepuasan Kerja (Y) & 0,602 & 0,1775 & Valid \\
& Y.3 & 0,429 & 0,1775 & Valid \\
& Y.4 & 0,488 & 0,1775 & Valid \\
& Y.5 & 0,537 & 0,1775 & Valid \\
& Y.7 & 0,457 & 0,1775 & Valid \\
& Y.8 & 0,551 & 0,1775 & Valid \\
& Y.9 & 0,416 & 0,1775 & Valid \\
& Y.10 & 0,629 & 0,1775 & Valid \\
\end{tabular}

Sumber: Data diolah, 2018

\section{Kompensasi dan kepuasan kerja}

Berdasarkan Tabel 2 terlihat bahwa nilai $\mathbf{r}_{\text {hitung }}$ setiap item variabel kepuasan kerja lebih besar dari nilai $r$ tabel atau $r$ hitung $>r$ tabel dimana batas angka kritis adalah 0,05 dan $\mathrm{n}=87$ maka diperoleh $\mathrm{r}$ tabel sebesar 0,1775. Maka dapat disimpulkan variabel kepuasan kerja bersifat valid. 


\section{Uji reliabilitas}

Reliabilitas adalah alat untuk mengukur suatu kuesioner yang merupakan indicator dari suatu variabel. Suatu variabel dikatakan reliable atau handal jika jawaban pernyataan adalah konsisten atau stabil dari waktu ke waktu (Ghozali, 2011). Pengujian reliabilitas dilakukan dengan bantuan komputer menggunakan program SPSS for Windows Versi 17, koefisien Cronbach's Alpha yang umumnya digunakan sebagai persyaratan sebuah alat ukur diatas 0,6. Hasil pengujian reliabilitas pada penelitian ini dapat dilihat sebagai berikut:

Tabel 3. Hasil uji realibilitas

\begin{tabular}{lcl}
\hline \multicolumn{1}{c}{ Variabel } & Cronbach's Alpha & Keterangan \\
\hline Kompensasi & 0,799 & Reliabel \\
Kepuasan Kerja & 0,707 & Reliabel \\
\hline
\end{tabular}

Sumber: Data diolah, 2018

Berdasarkan hasil pengujian reliabilitas instrumen pada tabel menunjukkan bahwa seluruh instrumen yang diajukan untuk variabel kompensasi dan kepuasan kerja memiliki nilai Cronbach's Alpha lebih besar dari angka 0,6. Maka dapat disimpulkan bahwa semua variabel dalam penelitian ini bersifat reliable atau handal.

Tabel 4. Variabel kompensasi

\begin{tabular}{ccc}
\hline Dimensi & Rata-rata Skor & Kategori \\
\hline Kompensasi finansial & 292,2 & Cukup baik \\
Kompensasi non finansial & 279,5 & Cukup baik \\
\hline Jumlah & $\mathbf{5 7 1 , 7}$ & Cukup baik \\
\hline Rata-rata & $\mathbf{2 8 5 , 9}$ & \\
\hline
\end{tabular}

Sumber: Data diolah, 2018

Berdasarkan Tabel 4, maka dapat diketahui bahwa secara keseluruhan rata-rata skor pada variabel kompensasi di PT. Sumber Hijau Permai (SHP) Jambi adalah sebesar 285,9 dan termasuk dalam kategori cukup baik karena berada pada rentang skala 226,4 - 296. Maka dapat disimpulkan bahwa kompensasi di PT. Sumber Hijau Permai (SHP) Jambi diimplementasikan cukup baik.

Tabel 5. Variabel kepuasan kerja

\begin{tabular}{ccc}
\hline Dimensi & Rata-rata skor & Kategori \\
\hline Pekerjaan & 297,5 & Puas \\
Upah & 286 & Cukup puas \\
Promosi & 287,5 & Cukup puas \\
Pengawasan & 293 & Cukup puas \\
Rekan kerja & 302 & Cukup puas \\
\hline Jumlah & $\mathbf{1 4 6 6}$ & Cukup puas \\
\hline Rata-rata & $\mathbf{2 9 3 , 2}$ &
\end{tabular}

Sumber: Data diolah, 2018 


\section{Uji regresi linear sederhana}

Dalam penelitian ini, analisis regresi linear sederhana digunakan untuk mengetahui pengaruh suatu variabel terhadap variabel lain dan meramalkan nilai suatu variabel apabila variabel lain diketahui. Untuk lebih memudahkan dalam pengerjaan dan agar hasilnya lebih akurat, maka dalam menganalisis data penulis menggunakan program SPSS versi 17 for Windows. Ringkasan hasil pengolahan data dengan menggunakan program SPSS diperoleh hasil regresi linear sederhana sebagai berikut:

Tabel 6. Hasil analisis regresi linear sederhana

\begin{tabular}{lccccc}
\hline \multirow{2}{*}{ Model } & \multicolumn{2}{c}{ Unstandardized Coefficients } & $\begin{array}{c}\text { Standardized } \\
\text { Coefficients }\end{array}$ & \multirow{2}{*}{ Sig. } \\
\cline { 2 - 4 } & $\mathbf{B}$ & Std.Error & Beta & & \\
\hline 1 (Constant) & 13.680 & 1.929 & .750 & 7.090 & .000 \\
Kompensa si & .672 & .064 & & 10.44 & .000 \\
\hline
\end{tabular}

a. Dependent variable: kepuasan

Sumber: Data diolah, 2018

Dari hasil analisis program SPSS for Windows 17.00, maka dapat diketahui persamaan regresi yang terbentuk. Adapun persmaan regresi linear yang terbentuk adalah:

Dari persamaan regresi tersebut dapat diartikan sebagai berikut:

$Y=13,680+0,672 X$

Konstan

Nilai konstanta sebesar 13,860 menyatakan jika kepuasan kerja nilainya 0 , maka variabel kompensasi akan mengalami peningkatan sebesar 13,860.

\section{Kompensasi}

Nilai variabel kompensasi sebesar 0,672. Hal ini mengandung arti bahwa setiap kenaikan variabel kompensasi maka vaiabel kepuasan kerja (Y) akan naik sebesar 0,672 dengan asumsi bahwa variabel bebas yang lain dari model regresi adalah tetap. Berdasarkan Tabel 6, maka dapat diketahui bahwa semua variabel memiliki nilai B (beta) yang positif dapat disimpulkan bahwa kompensasi memiliki pengaruh yang positif terhadap kepuasan kerja.

\section{Uji t (parsial)}

Dari Tabel 7 hasil perhitungan didapat nilai th ${ }_{\text {itung }} 10,445>\mathrm{t}_{\text {tabel }} 0,1775$ dengan tingkat signifikansi sebesar 0,000 hal ini berarti H0 ditolak dan H1 diterima, artinya bahwa ada pengaruh positif dan signifikan dari variabel bebas (kompensasi) terhadap variabel terikat (kepuasan kerja).

Tabel 7. Hasil Perhitungan uji t (parsial)

\begin{tabular}{lrrrrrr}
\multicolumn{1}{c}{ Model } & \multicolumn{2}{c}{$\begin{array}{c}\text { Unstandardized } \\
\text { Coefficients }\end{array}$} & $\begin{array}{c}\text { Standardized } \\
\text { Coefficients }\end{array}$ & \multirow{2}{c}{ t } & Sig. \\
\cline { 2 - 4 } & \multicolumn{1}{c}{ B } & Std.Error & Beta & & & \\
\hline 1 (Constant) & 13.680 & 1.929 & & 7.090 & .000 \\
Kompensasi & .672 & .064 & & .750 & 10.445 & .000 \\
\hline
\end{tabular}

a. Dependent variable: kepuasan

Sumber: Data diolah, 2019 


\section{Uji koefisien determinasi $\left(\mathbf{R}^{\mathbf{2}}\right)$}

Koefisien determinasi ( $\mathrm{R}$ square) pada intinya adalah mengukur seberapa jauh kemampuan model dalam menerangkan variasi dependen. Nilai koefisien determinasi adalah 0 dan 1 . Semakin besar $\mathrm{R}^{2}$ suatu variabel independen menunjukkan semakin dominannya pengaruh terhadap variabel dependennya. Maka dapat ditentukan koefisien determinasi Tabel 8.

Perhitungan di atas menunjukkan bahwa hubungan antara variabel kompensasi dengan variabel kepuasan kerja adalah sebesar 0,562. Yang berarti variabel independen berupa kompensasi mempengaruhi variabel dependen berupa kepuasan kerja sebesar $56,2 \%$ dan sedangkan sisanya $(100 \%-56,2 \%=43,8 \%)$ disebabkan oleh faktor-faktor lain yang tidak diungkapkan dalam penelitian ini.

Tabel 8. Hasil perhitungan nilai koefisien determinasi

\begin{tabular}{rrrrr}
\hline Model & R & R Square & Adjusted R Square & Std. Error of the Estimate \\
\hline 1 & $.750^{\mathrm{a}}$ & .562 & .557 & 2.79946
\end{tabular}

a. Predictors: (constant), kompensasi

Sumber: Data diolah, 2019

$$
\mathrm{D}=\mathbf{0 , 5 6 2} \times \mathbf{1 0 0 \%}
$$

\section{KESIMPULAN DAN SARAN}

\section{Kesimpulan}

Gambaran variabel kompensasi dan kepuasan kerja karyawan pada PT. Sumber Hijau Permai (SHP) Jambi. Kompensasi, Dari hasil pengujian deskriptif untuk dimensi kompensasi finansial diperoleh rata-rata skor sebesar 292,2 dalam kategori cukup baik. Sedangkan dimensi kompensasi non finansial diperoleh rata-rata skor 279,5 dalam kategori cukup baik. Dari kedua dimensi tersebut terlihat bahwa dimensi kompensasi non finansial yang paling rendah. Kompensasi non finansial terdiri dari empat indikator, yaitu pujian, penghargaan, pengakuan, dan cuti kerja. Dari keempat indikator tersebut, diperoleh skor tertinggi yaitu pada indikator pujian dan skor terendah yaitu pada indikator pengakuan.

Kepuasan Kerja, Dari hasil pengujian deskriptif untuk variabel kepuasan kerja diperoleh rata-rata skor secara keseluruhan sebesar 292,2 termasuk dalam kategori cukup puas. Variabel kepuasan kerja terdiri dari lima dimensi yaitu, pekerjaan, upah, promosi,pengawasan, dan beban kerja. Berdasarkan dimensi-dimensi diatas, diperoleh rata-rata skor tertinggi yaitu pada dimensi beban kerja dalam kategori puas. Dan rata-rata skor terendah yaitu pada dimensi upah dalam kategori cukup puas.

Pengaruh Kompensasi Terhadap Kepuasan Kerja Berdasarkan uji hipotesis yang dilakukan dengan menggunakan uji secara parsial, diperoleh nilai thitung > ttabel maka dapat disimpulkan bahwa secara parsial terdapat pengaruh positif dan signifikan antara kompensasi dengan kepuasan kerja karyawan. Selain itu pula untuk melakukan uji berdasarkan pengujian signifikansi, diperoleh nilai signifikansi lebih $<0,05$, sehingga dapat disimpulkan bahwa kompensasi berpengaruh positif dan signifikan terhadap kepuasan kerj a karyawan.

\section{Saran}

Berdasarkan hasil dari dimensi. kompensasi non finansial terlihat bahwa skor terendah yaitu pada indikator pengakuan. Oleh karena itu diharapkan pimpinan memberikan pengakuan kepada karyawan atas hasil kerja yang telah dilakukan, dan juga perusahaan memberikan cuti bagi para karyawan yang sakit dan dalam masa pemulihan. 
Disarankan pada PT. Sumber Hijau Permai (SHP) Jambi sebaiknya memberikan gaji karyawan yang sesuai dengan beban kerja dan tanggung jawabnya dan memberikan gaji tepat waktu agar karyawan akan merasa termotivasi untuk melakukan pekerjaannya dengan baik.

Disarankan kepada peneliti yang Selanjutnya untuk tidak melakukan penelitian dengan judul yang sama dengan penelitian ini, dikarenakan dari hasil penelitian yang sudah dilakukan dapat dilihat presentase pengaruh kompensasi terhadap kepuasan kerja yaitu sebesar 52,6\% ini termasuk dalam kategori besar pengaruh yang terjadi antara variabel kompensasi terhadap kepuasan kerja. untuk peneliti selanjutnya disarankan agar meneliti variabel lain untuk bisa dibandingkan.

\section{DAFTAR PUSTAKA}

Agung Panudju., Yusuf Haryono., Sindu Cahyoko., Andira., \& Budiarto Subroto. (2003). Pengaruh kompensasi dan karakteristik pekerjaan terhadap kepuasan kerja karyawan unit produksi produksi PT.X Palembang. Jurnal Manajemen \& Bisnis.

Akbar, Arif Muhammad. (2012). Analisis faktor-faktor kepuasan kerja pegawai pada kantor Dinas Perindustrian dan Perdagangan Provinsi Jambi, Skripsi. Jambi:Universitas Jambi.

Handoko, T. Hani. (2007). Manajemen. Yogyakarta: BPFE.

Hasibuan, Malayu. (2007). Manajemen sumber daya manusia. Jakarta: Bumi Aksara.

Hasibuan, Malayu. (2010). Manajemen dasar pengertian, dan masalah. Jakarta: CV Haji Masagung.

Hasibuan, Malayu. (2014). Manajemen, dasar pengertian dan masalah. Jakarta: Bumi Aksara.

Hasibuan, Malayu. (2012). Manajemen sumber daya manusia. Jakarta: Bumi Aksara.

Kaswan. (2012). Manajemen sumber daya manusia untuk keunggulan bersaing organisasi. Graha Ilmu, Yogyakarta.

Kasmir. (2016). Manajemen sumber daya manusia (teori dan praktik), Jakarta: PT.Raja Grafindo Persada.

Mangkunegara, Anwar. (2012). Manajemen sumber daya manusia. Bandung: PT.Refika

Robbins, Stephen P. dan Judge, Timothy A. (2009). Organizational behavior. Edition. Pearson Education, Inc., Upper Saddle River, New Jersey.

Robbins, S dan Coulter, M. (2007). Manajemen. Edisi Kedelapan, Jakarta: PT Indeks.

Riva'i, veithzal. (2009). Manajemen sumber daya manusia, Jakarta: Kencana Prenada Media Group.

Sedarmayanti. (2009). Sumber daya manusia dan produktivitas kerja, Bandung: CV Mandar Maju.

Sopiah dan L. Muthis Robert. (2008). Perilaku organisasi. Yogyakarta: Andi.

Sunyoto, Danang. (2015). Penelitian sumber daya manusia. Jakarta : CAPS.

Sunyoto, Danang., \& Moh As'ad. (2013). Perilaku organisasi. Jakarta: Salemba Empat.

Sutrisno, Edy. (2009). Manajemen sumber daya manusia. Jakarta: Kencana Prenada Media Group.

Tatit Diansari Reskiputri. (2015). Pengaruh lingkungan kerja dan kompensasi terhadap kepuasan kerja melalui disiplin dan semangat kerja karyawan pada PT. Bank Jatim, Tbk Cabang Jember.

Yani, H.M. (2012). Manajemen sumber daya manusia. Jakarta: Mitrawacana Media. 